\title{
EFFECT OF BIRTHWEIGHT, ILLNESS HISTORY, AND DIETARY PATTERN, ON THE INCIDENCE OF ANEMIA IN CHILDREN UNDER-FIVE AT TASIKMADU HEALTH CENTER, KARANGANYAR, CENTRAL JAVA
}

\author{
Yeni Anggraini ${ }^{1,2)}$, Harsono Salimo3), Didik Gunawan Tamtomo4) \\ 1) Diploma Program in Health Sciences Mitra Husada, Karanganyar, \\ Central Java \\ 2) Masters Program in Public Health, Sebelas Maret University \\ 3)Department of Pediatrics, Faculty of Medicine, Sebelas Maret University \\ 4)Department of Anatomy, Faculty of Medicine, Sebelas Maret University
}

\begin{abstract}
Background: The first five years of life is often regarded as "golden age period" of development. During this period physical, motor, intellectual, emotional, language, and social development proceed rapidly in children. Brain tissues grow fast to reach $80 \%$ of adult brain weight. Anemia occuring during this period can affect health, as well as cognitive and physical development in children. This study aimed to determine the effects of birthweight, illness history, dietary pattern, maternal education, and family income on the incidence of anemia in children under-five years of age.

Subjects and Method: This was an analytic observational study using case control design. The study was carried out at Karanganyar District, Central Java, from February to April 2017. A sample of 110 subjects was selected for this study, consisting of 35 children under-five years of age with anemia and 75 children of the same age without anemia. The independent variables were birthweight, illness history, dietary pattern, maternal education, and family income. The dependent variable was anemia. The data were collected by a set of questionnaire. Hemoglobin concentration was measured by $\mathrm{Hb}$ meter. The data were analyzed by path analysis on Stata 13 .

Results: Anemia in children under-five was directly affected by illness history $(b=2.50 ; 95 \% \mathrm{CI}=1.06$ to $3.95 ; \mathrm{p}=0.001 ;)$, dietary pattern $(\mathrm{b}=-1.89$; $95 \% \mathrm{CI}=-3.39$ to $-0.39 ; \mathrm{p}=0.013 ;)$, and birthweight $(\mathrm{b}=-0.97 ; 95 \% \mathrm{CI}=-2.07$ to $0.13 ; \mathrm{p}=0.083)$. Anemia in children under-five was indirectly affected by maternal educational $(\mathrm{b}=1.09 ; 95 \% \mathrm{CI}=0.14-2.04 ; \mathrm{p}=0.024)$ and family income $(b=-0.90 ; 95 \% \mathrm{CI}=-1.78$ to $0.02 ; \mathrm{p}=0.044)$.

Conclusion: Anemia in children under-five is directly affected by illness history, dietary pattern, and birthweight. It is indirectly affected by maternal educational and family income.
\end{abstract}

Keywords: anemia, birthweight, illness history, dietary pattern, children under-five

Correspondence: Yeni Anggraini. Masters Program in Public Health, Sebelas Maret University, Jl. Ir. Sutami 36 A, Surakarta 57126, Central Java, Indonesia. Email: yenni.anggrainie@gmaill.com. Mobile: +6285712329100. 